\title{
Diagnostic accuracy of fine-needle aspiration cytology in histological grade 1 breast carcinomas: are we good enough?
}

Mehran Karimzadeh, medical student, University of Oslo, Norway Torill Sauer MD, PhD, Department of Pathology, Ullevaal University Hospital and Faculty of Medicine, University of Oslo, Norway

Corresponding author:

Torill Sauer MD, PhD, Department of Pathology, Ullevaal University Hospital and Faculty of Medicine, University of Oslo, N-0407 Oslo, Norway

Tel: +4722118921

Fax: +4722118239

e-mail: torill.sauer@medisin.uio.no

Financial disclosures and conflicts of interest: none 
Abstract

BACKGROUND: Fine-needle aspiration cytology (FNAC) of both palpable and nonpalpable breast carcinomas has a high accuracy and sensitivity in dedicated centres. It is generally though that low-grade carcinomas have a distinctly lower sensitivity due to a discrete cellular atypia that might be difficult to appreciate. Grade 1 carcinomas make up about $45 \%$ of screening detected breast carcinomas and about $20 \%$ of symptomatic breast cancers. The aim of this study was to evaluate the diagnostic sensitivity of G1 carcinomas and identify the critical features in the cytological diagnostic work-up of these tumours.

MATERIAL AND METHODS: There were FNAC smears from 494 histologically confirmed grade 1 carcinomas diagnosed during 1996-2004. The cytological diagnoses were compared with the histology.

RESULTS: A definitive malignant diagnosis was given in 382 cases (77.3 \%). $16.2 \%$ were diagnosed as equivocal or suspicious, $4.8 \%$ had been given a benign or probable benign diagnosis (false negatives). 13 cases (2.6\%) were unsatisfactory. The complete sensitivity was $92.7 \%$. Invasive ductal carcinomas comprised $81.3 \%$ of all cases. A definite malignant preoperative diagnosis was given in $80.8 \%$ of these. Invasive lobular and tubular carcinomas comprised $7.1 \%$ and $5.5 \%$ of cases, respectively. They received a definitive, malignant preoperative diagnosis in $51.4 \%$ and $55.6 \%$, respectively.

CONCLUSION: Preoperative FNAC diagnosis of grade 1 breast carcinoma has a high accuracy and sensitivity, especially in ductal carcinomas. Invasive lobular and tubular carcinomas receive a definite preoperative diagnosis in about $50 \%$ of the cases. The main reason for not reaching a definitive malignant diagnosis was 
sampling error due to small tumours $\leq 1 \mathrm{~cm}$ in diameter, irrespective of tumour subtype.

Key words: breast carcinoma, grading, fine needle aspiration, grade 1 carcinoma, pleomorphism, nuclear size, dissociation pattern.

Introduction

Fine needle aspiration cytology (FNAC) is an integral part of the preoperative multidisciplinary triple approach in the work-up of both symptomatic and screening detected breast lesions in many institutions. Breast FNAC of palpable and non palpable lesions is reliable and cost effective. The literature reports sensitivity and specificity ranging from around $60 \%$ to $100 \%$. (1-23) When integrated into the assessment process, it reduces the benign biopsy rate (24). When integrated in the triple test, the chance of detecting a malignant lesion is well over $99 \%$. The breast cancer screening programme in Norway has caused a considerable increase in the incidence of low-grade carcinomas. The first screening rounds showed that up to $45 \%$ of detected carcinomas were histological grade 1 (25) in contrast to about $20 \%$ in symptomatic tumours. It has been generally assumed that the accuracy in diagnosing low-grade breast carcinomas on FNAC is substantially lower than in grade 2 and 3 carcinomas, resulting in a high degree of false negative diagnoses in grade 1 breast carcinomas and hence in a large proportion of screening detected breast carcinomas. Some studies have shown that a significant number of false negatives may be caused by interpretation failure of certain histological subtypes, such as lobular (ILC), tubular (TUB), adenosquamous and papillary carcinomas $(26 ; 27)$. The aim of this study was to investigate our results of FNAC on histological grade 1 symptomatic and screening detected breast carcinomas. 
Material and methods

Records from 839 cases of histological grade 1 breast carcinomas diagnosed during 1996 - 2004 were retrieved from the files of the department of Pathology, Ullevaal University Hospital (UUS). About $1 / 3$ had been preoperatively investigated outside UUS and FNAC was not available. Smears submitted from one external radiologist were omitted, and only cases where the cytopathologists in our department had done the aspiration were primarily included. Cases which on review revealed a dominant DCIS on histology and where it was obvious that cell material from the DCIS component was predominant in the smears were excluded. Lastly, the relevant, diagnostic smears could not be found in two cases. This left us with FNAC from 494 histological confirmed grade 1 carcinomas. Both Papanicolaou (ethanol spray fixation) and Giemsa (air dried and methanol fixed) stained smears were evaluated. The general diagnostic cytological categories and criteria used in the department are given in table 1.

TNM and grading was taken from the pathology records. The grading had been done according to Elston and Ellis' modification of Bloom and Richardson (28;29). The histological grading was not reviewed. The preoperative cytological diagnoses as well as eventual suggestion of subtypes of carcinoma were recorded. The smears were also evaluated for amount of cell material (scant, moderate or abundant) as well as microcalcifications and myoepithelial cells.

In addition the type of error was evaluated (interpretation vs. sampling error). A diagnosis of less than "carcinoma" in good quality smears with moderately and/or abundant cellularity was evaluated as interpretation error. Suboptimal smears with any kind of technical fault (crush artefacts, improper fixation) and/or scant cellularity were regarded as sampling error. This included smears with no or a limited number 
of benign appearing epithelial cells where it was obvious that the tumour had been missed on aspiration.

One observer (MK) evaluated 380 cases independently as part of a medical student's project. 242 of these were also evaluated by joint microscopy by the two observers. Observer two (TS) evaluated the rest independently and overruled observer one in cases of discrepancies. The rest of the cases were evaluated by TS alone. As this was a student's project, no inter observer evaluation was done.

Results

$80.3 \%$ of the carcinomas were pT1, $18.2 \%$ were pT2 and $1.5 \%$ pT3 and pT4, respectively. $50.1 \%$ of cases were N0, $16.6 \%$ were $\mathrm{N}+$ and $33.3 \%$ were NX. An overview of the other results is shown in tables 2 and 3 . There were $4.8 \%$ false negatives (benign and probably benign cases) (FN) whereas $2.6 \%$ were unsatisfactory for diagnosis (table 2). $68.8 \%$ of the unsatisfactory cases were from tumours $<1 \mathrm{~cm}$ in diameter (pT1a and pT1b). Three pT2 cases with unsatisfactory FNAC were all ILC.

The complete sensitivity was $92.5 \%$ (434 cases), whereas the absolute sensitivity was $77.3 \%$ (382 cases).

Invasive ductal carcinomas (IDC) comprised $83.4 \%$ of cases (figure 1). ILC and TUB (figures 2, 3A and 3B) made up $5.5 \%$ and $4.5 \%$, respectively. In 397 (80.3 \%) cases a cytological subtype was suggested. $89.6 \%$ of the cases described as ductal on cytology were concurrent with the histological sub typing, whereas only $40 \%$ of ILC and TUB were correctly suggested as subtype on FNAC. 
Sampling error (SE) was the main cause of not reaching a definite diagnosis of malignancy on FNAC (66.1 \% of cases). In ILC and TUB SE made up $>82 \%$ of cases. Scant cell material was found in $19.7 \%$ of cases and made up $86.7 \%$ of cases with a benign FNAC diagnosis, $75 \%$ of the probably benign cases and $70 \%$ of the equivocal cases. These and $42.9 \%$ of the suspicious cases made up the SE cases. $10.1 \%$ were given a definite diagnosis of malignancy in spite of the scant cellularity.

Abundant cell material was noted in $50.7 \%$ of the cases. None of these had been given a benign diagnosis, but $12.5 \%$ had been diagnosed as probably benign, $10 \%$ as equivocal and $18.4 \%$ as suspicious and representing interpretation error (IE) cases. Scattered myoepithelial cell nuclei were found at the periphery of epithelial (carcinoma) cell groups (but not in the background) in $20.2 \%$ of IDC and $39.1 \%$ of TUB. Microcalcifications were found in $45 \%$ of all cases.

\section{Discussion}

Sensitivity, percentage of inadequate smears and FN in FNAC of grade 1 breast carcinomas are all well within the QC recommendations in the Norwegian breast screening programme (21). The sensitivity is marginally lower than in previous results from non-palpable breast lesions (22). This is in agreement with the fact that $80 \%$ of the carcinomas in this study were $\leq 10 \mathrm{~mm}$ and the vast majority would have been non-palpable (this feature had not been recorded). In a previous report of the first four years of mammography screening in Oslo (21) we found an absolute and complete sensitivity of $81 \%$ and $91 \%$, respectively. The sensitivity of FNAC ranges in the literature from 65 to $98 \%$ (7). It reflects both aspirator and interpretation skills. 
FNAC is highly operator dependent $(7 ; 30 ; 31)$. Aspirator skill is also reflected in the inadequacy rate, which was $2.6 \%$ in this study.

Subtyping of carcinomas on cytological material revealed significant differences between IDC, ILC and TUB (table 3). Almost $90 \%$ of IDC were correctly subclassified as such on cytology, whereas only $40 \%$ of ILC and TUB were correctly sub-classified. Both ILC and TUB have characteristic cytological features reported in the literature (32-43), but none of them are restricted to one subtype only. IDC has a wide range of histological appearances which may be reflected in FNAC. They include features that may also be found in other subtypes. Also, IDC may harbour components of other subtypes such as tubular, mucinous, papillary and lobular which may be found in the smears. The most important is to recognise a papillary subtype, as these may present as a tumour both clinically and radiologically and still be an in situ lesion on histology. The problem of diagnosing in situ versus invasive lesions has been addressed previously $(21 ; 44)$. In case of a cytological papillary carcinoma, we do not attempt to predict eventual invasive growth. The lesion will be resected with free margins, but the sentinel node will not be removed. Apart from that, subtyping does not affect the primary management of the women and is not essential.

Sampling error (SE) was the main cause of not giving a preoperative definite malignant diagnosis irrespective of tumour type (table 3) and the main cause of SE was small tumour size $(80 \% \leq 1 \mathrm{~cm})$. In IDC the causes were rather mixed and both sampling and interpretation might be a problem.

Sampling is a well known problem in ILC and is due to the abundant sclerotic stroma that is found in most cases. The carcinoma cells usually present with a low - grade, but recognizable atypia, but the cells are characteristically few in numbers. The 
characteristic finding in FNAC from ILC would be scant to moderate amount of cells (table 3) diagnosed as suspicious (28.6\%) or as malignant (51.4\%) and where the reservation in the diagnosis is due to a low number of carcinoma cells on the smears $(82.4 \%$, see table 2$)$.

TUB present little atypia in contrast to most IDC, and may be misdiagnosed as fibroadenoma or fibrocystic changes (33;34). Cellular features such as angular tubular structures, single epithelial cells, absence of or paucity of bare oval nuclei are frequently described as distinguishing features (32;33). TUB represented a diagnostic problem as they frequently eluded detection on cytology. 8 (30\%) cases were diagnosed as benign, probably benign or equivocal. $55.6 \%$ (= absolute sensitivity) was given a definitive preoperative diagnosis in our study, whereas the complete sensitivity (malignant + suspicious + equivocal) was $85 \%$. Mitnick et al. (42) showed an absolute sensitivity of $42 \%$, which is somewhat lower than our findings. Cangiarella et al. (33) showed a complete sensitivity of $86 \%$. Despite the discrete cellular and nuclear atypia of TUB, the main cause of not reaching a definitive malignant diagnosis in our material was sampling (table 2). Although there is a higher false negative rate of TUB and ILC than of ductal carcinoma, the combined incidence comprised only $10 \%$ of the total number of cases. Overall, ILC will make up a larger group, though, as many of them are diagnosed as grade 2 (G2).

There has been an increase in the use of core biopsy (CNB) in the recent years $(45 ; 46)$. CNB has a higher sensitivity for ILC and TUB (42), but considering the incidence, it would be cost efficient and time saving to use FNAC as a first line investigation. Combination of CNB and FNAC has shown a higher sensitivity than FNAC alone (12). However, if the sensitivity of FNAC is high, the additional value of a 
CNB will have a marginal effect on the sensitivity. In addition, sampling of small and focal lesions is known to cause diagnostic difficulties even in CNB (47).

Myoepithelial cells were found in a subpopulation of IDC and TUB (20 \% and $39 \%$, respectively), but always in limited numbers. It is important to know this and not diagnose these lesions as benign or probably benign on account of a few myoepithelial cells.

Microcalcifications were a common finding in IDC and TUB (45\% and $65 \%$, resepectively), but were non-contributory in the diagnostic work-up.

In conclusion, FNAC had a high sensitivity in diagnosing low - grade invasive carcinomas. The main difficulties encountered were related to SE, irrespective of tumour subtype. Small tumour size was the main cause of SE. In contrast to what might have been anticipated, IDC had the largest proportion of interpretation problems. 


\section{Reference List}

1. Azavedo E, Svane G, Auer G. Stereotactic fine-needle biopsy in 2594 mammographically detetcted non-palpable lesions. Lancet 1989;13:1033-6.

2. Brown LA, Coghill SB. Cost effectiveness of a fine needle aspiration clinic. Cytopathology 1992;3:275-80.

3. Choi YD, Choi YH, Lee J-H, Nam JH, Juhng S-W, Choi C. Analysis of fine needle aspiration cytology of the breast: a review of 1,297 cases and correlation with histologic diagnoses. Acta Cytologica 2004;48:801-6.

4. Crotch-Harvey MA, Loughran CF. Combined stereotactic wide-core needle biopsy and fine-needle aspiration cytology in assessment of impalpable mammographic abnormalities detetced in a breast-screening programme. The Breast 1996;5:48-9.

5. Dennison G, Anand R, Makar SH, Pain JA. A prospective study of the use of fine-needle aspiration cytology and core biopsy in the diagnosis of breast cancer. Breast J 2003;9:491-3.

6. Fessia L, Botta G, Arisio R, Varga M, Aimone V. Fine-Needle Aspiration of Breast Lesions: Role and Accuracy in a Review of 7495 Cases. Diagnostic Cytopathology 1987;3:121-5.

7. Giard RWM, Hermans J. The value of aspiration cytologic examination of the breast. Cancer 1992;69:2104-10. 
8. Hammond S, Keyhani-Rofhaga S, O'Toole RV. Statistical Analysis of Fine Needle Aspiration Cytology of the Breast. A Review of 678 Cases Plus 4265 cases from the Literature. Acta Cytologica 1987;31:276-80.

9. Hitccock A, Hunt CM, Locker A. A one year audit of fine needle aspiration cytology for the preoperative diagnosis of breast disease. Cytopathology 1991;2:167-76.

10. Horgan PG, WIdron D, Moonay E, O'Brian D, McGuire M, Given HF. The role of aspiration cytologic examination in the diagnosis of carcinoma of the breast. Surg Gynecol Obstet 1991;172:290-2.

11. Kocjan G. Evaluation of the cost effectiveness of establishing a fine needle aspiration cytology clinic in a hospital out-patient department. Cytopathology 991;2:13-8.

12. Leifland K, Lagerstedt U, Svane G. Comparison of Stereotactic Fine Needle Aspiration Cytology and Core Needle Biopsy in 522 Non-Palpable Breast Lesions. Acta Radiologica 2003;44:387-91.

13. Medina-Franco H. Fine needle aspiration biopsy of breast lesions: institutional experience. Rev Invest Clin 2005;57:394-8.

14. Mitnick JS, Vazquez MF, Pressman PI, Harris MN, Roses DF. Stereotactic fineneedle aspiration biopsy for the evaluation of nonpalpable lesions: report of an experience based on 2988 cases. Annals of Surgical Oncology 1996;3:185-91. 
15. Nasuti JF, Gupta PK, Baluch ZW. Diagnostic value and cost-effectiveness of onsite evaluation of fine-needle aspiration specimens: Review of 5688 cases. Diagnostic Cytopathology 2002;27:1-4.

16. Okamoto H, Ogawara T, Inoue S, Kobayashi K, Sekokawa T, Matsumoto Y. Clinical management of nonpalpable or small breast masses by fine-needle aspiration biopsy (FNAB) under ultrasound guidance. J Surg Oncol 1998;67:246-50.

17. Pisano ED, Fajardo LL, Caudry DJ, Sneige N, Frable WJ, Berg WA et al. FineNeedle Aspiration Biopsy of Nonpalpable Breast Lesions in a Multicenter Clinical Trial: Results from the Radiologic Diagnostic Oncology Group V. Radiology 2001;219:785-92.

18. Rubin M, Horiuchi K, Joy N, Haun W, Read R, Ratzer E et al. Use of fine needle aspiration for solid breast lesions is accurate and cost-effective. American Journal of Surgery 1997;174:694-6.

19. Saarela AO, Kiviniemi HO, Rissanen TJ, Paloneva TK. Nonpalpable breast lesions: pathologic correlation of ultrasonographical needle aspiration biopsy. Journal of Ultrasound Medicine 1996;15:549-53.

20. Saravanja S. Ultrasound-guided fine-needle aspiration of the breast. Schweiz Rundsch Med Prax 2005;94:673-9.

21. Sauer T, Young K, Thoresen S $\varnothing$. Fine needle aspiration cytology in the work-up of mammographic and ultrasonographic findings in breast cancer screening: an attempt at differentiating in situ and invasive carcinoma. Cytopathology 2002;13:101-10. 
22. Sauer T, Myrvold K, Lømo J, Anderssen KY, Skaane P. Fine-needle aspiration cytology in nonpalpable mammographic abnormalities in breast cancer screening: results from the breast cancer screening programme in Oslo 19962001. The Breast 2003;12:314-9.

23. Vetrani A, Fulciniti F, Di Benedetto G, Zeppa P, Troncone G, Boscaino A et al. Fine-needle aspiration biopsies of breast masses. An additional experience with 1153 cases (1985 to 1988) and a metaanalysis. Cancer 1992;69:736-40.

24. Lamb J, Anderson TJ. Influence of cancer histology on the success of fine needle aspiration of the breast. J Clin Pathol 1989;42:733-5.

25. Wang $\mathrm{H}$, Hofvind SS-H, Thoresen $\mathrm{S} \varnothing$. A pilot project with organised mammography screening: results from the first screening round. Tidsskr Nor Lægeforen 2000;120:3237-40.

26. Lamd J, McGoogan E. Fine needle aspiration cytology of breast invasive carcinoma of tubular type and in radial scar/complex sclerosing lesions. Cytopathology 1994;5:17-26.

27. Layfield LJ, Dodd LG. Cytologically low grade malignacies: an important interpretative pitfall responsible for false negative diagnoses in fine-needle aspiration of the breast. Diagn Cytopathol 1996;15:250-9.

28. Bloom HJ, Richardson WW. Histological grading and prognosis in breast cancer; a study of 1409 cases of which 359 have been followed for 15 years. $\mathrm{Br}$ J Cancer 1957;11:359-77. 
29. Elston CW, Ellis IO. Assessment of histological grade. The Breast, Third Edition ed. Edinburgh: Churchill-Livingstone, 1998:365-84.

30. Lee KR, Foster RS, Papillo JL. Fine needle aspiration of the breast: Importance of the aspirator. Acta Cytologica 1987;31:281-4.

31. Ljung BM, Drejet A, Chiampi N, Jeffrey J, Goodson WH. Diagnostic accuracy of fine-needle aspiration biopsy is determined by physician training in sampling technique. Cancer 2001;22:126-30.

32. Bondeson L, Lindholm K. Apiration cytology of tubular breast carcinoma. Acta Cytol 1990;34:15-20.

33. Cangiarella J, Waisman J, Shapiro RL, Simsir A. Cytologic features of tubular adenocarcinoma of the breast by aspiration biopsy. Diagn Cytopathol 2001;25:15-20.

34. Dawson AE, Logan-Young W, Mulford DK. Aspiration cytology of tubular carcinoma. Diagnostic features with mammographic correlation. Am J Clin Pathol 2006;101:488-92.

35. de la Torre M, Lindholm K, Lindgren A. Fine needle aaspiration cytology of tubular breast carcinoma and radial scar. Acta Cytol 1994;38:884-90.

36. Dei Tos AP, Della Giustina D, De Martin V, Della Libera D, Bittesini L. Aspiration biospy cytology of tubular carcinoma of the breast. Diagn Cytopathol 1994;11:146-50.

37. Fischler DF, Sneige N, Ordonez NG, Fornage BD. Tubular carcinoma of the breast: cytologic features in fine-needle aspirations and application of 
monoclonal anti-alpha-smooth muscle actin in diagnosis. Diagn Cytopathol 1994;10:120-3.

38. Greely CF, Frost AR. Cytologic features of ductal and lobular carcinoma in fine needle aspirates of the breast. Acta Cytol 1997;41:333-40.

39. Gupta RK, Dowle CS. Fine needle aspiration cytology of tubular carcinoma of the breast. Acta Cytol 1997;41:1139-43.

40. Jayaram G, Swain M, Chew MT, Yip CH. Cytologic apperances in invasive Iobular carcinoma of the breast. A study of 21 cases. Acta Cytol 2000;44:16974.

41. Joshi A, Kumar N, Verma K. Diagnostic challenge of lobular carcinoma on aspiration cytology. Diagn Cytopathol 1998;18:179-83.

42. Mitnick JS, Gianutsos R, Pollack AH, Susman M, baskin BL, Ko WD et al. Tubular carcinoma of the breast: sensitivity of diagnostic techniques and correlation with histopathology. AM J Roentgenol 1999;172:319-23.

43. Rajesh L, Dey P, Joshi K. Fine needle aspiration cytology of lobular carcinoma. Comparison with other breast lesions. Acta Cytol 2003;47:177-82.

44. Sauer T, Garred $\varnothing$, Lømo J, Næss O. Assessing invasion criteria in fine-needle aspirates from breast carcinomas diagnosed as ductal carcinoma in situ (DCIS) or invasive carcinoma: can we identify an invasive component in addition to the DCIS? Acta Cytol 2006;50:263-70.

45. Levine T. Breast cytology - is there still arole? Cytopathology 2004;15:293-6. 
46. Tabbara SO, Frost AR, Stoler MH, Sneige N, Sidaway MK. Changing trends in breast fine-needle aspiration: results of the Papanicolaou society of cytopathology survey. Diagn Cytopathol 2006;22:126-30.

47. Verkooijen HM. Diagnostic acuuracy of stereotactic large-core biopsy for nonpalpable breast disease: results of a multicenter prospective study with $95 \%$ surgical confirmation. Int J Cancer 2002;99:853-9. 
Table1. Diagnostic categories and criteria

\begin{tabular}{|l|l|}
\hline Cytological diagnostic categories & Cytological diagnostic criteria \\
\hline unsatisfactory & No/(too few epithelial cell groups present \\
\hline Benign NOS & $\begin{array}{l}\text { Sheets/groups of benign apocrine and/or } \\
\text { ductal epithelial cells; a variable number } \\
\text { of naked (myoepithelial) nuclei in the } \\
\text { background and recognisable } \\
\text { myoepithelial nuclei on a number of } \\
\text { benign epithelial sheets and groups }\end{array}$ \\
\hline Equivocal & $\begin{array}{l}\text { Epithelial cells with nuclear changes of } \\
\text { uncertain significance }\end{array}$ \\
\hline Suspicious for carcinoma & $\begin{array}{l}\text { Epithelial cells with some, but not } \\
\text { sufficient diagnostic features of } \\
\text { carcinoma; often scant cell material }\end{array}$ \\
\hline Carcinoma & $\begin{array}{l}\text { Variable, buy most often a high cell yield; } \\
\text { single population of atypical epithelial } \\
\text { cells in irregular and angular clusters; } \\
\text { reduced cohesiveness, variable, nuclear } \\
\text { enlargement and irregularity; single cells } \\
\text { with intact cytoplasm; absence of naked } \\
\text { (myoepithelial) nuclei in the background }\end{array}$ \\
\hline
\end{tabular}

Table2.Cytologic diagnoses

\begin{tabular}{|l|c|c|}
\hline & frequency & percent \\
\hline unsatisfactory & 13 & 2.6 \\
\hline benign & 16 & 3.2 \\
\hline $\begin{array}{l}\text { Hyperplasia/ } \\
\text { Probably benign }\end{array}$ & 8 & 1.6 \\
\hline Equivocal & 23 & 4.7 \\
\hline $\begin{array}{l}\text { Suspicious for } \\
\text { carcinoma }\end{array}$ & 52 & 10.5 \\
\hline Invasive carcinoma & 382 & 77.3 \\
\hline total & 494 & \\
\hline
\end{tabular}


Table3. Results of cytologic subtype, cytologic diagnosis, type of error, amount of cell material and microcalcification compared to histologic subtype.

\begin{tabular}{|c|c|c|c|c|c|c|c|}
\hline \multicolumn{8}{|c|}{ Histologic subtype } \\
\hline & ductal & lobular & tubular & mucinous & papillary & other & subtotal \\
\hline \multicolumn{8}{|l|}{$\begin{array}{l}\text { Cytologic subtype } \\
\text { (when suggested = } \\
397 \text { cases) } \\
\text { ) }\end{array}$} \\
\hline $\begin{array}{l}\text { carcinoma } \\
\text { NOS }\end{array}$ & $\begin{array}{c}106 \\
(86.2 \%)\end{array}$ & 11 & 4 & 2 & 0 & 0 & 123 \\
\hline - ductal & $\begin{array}{c}206 \\
(89.6 \%)\end{array}$ & 5 & 10 & 1 & 1 & 7 & 230 \\
\hline - lobular & 6 & $\begin{array}{c}6 \\
(46.2 \%)\end{array}$ & 1 & 0 & 0 & 0 & 13 \\
\hline - tubular & 2 & 0 & $\begin{array}{c}2 \\
(40 \%)\end{array}$ & 0 & 0 & 1 & 5 \\
\hline - mucinous & 4 & 0 & 1 & $\begin{array}{c}11 \\
(68.8 \%)\end{array}$ & 0 & 0 & 16 \\
\hline - papillary & 5 & 0 & 0 & 0 & 2 & 1 & 8 \\
\hline - other & 2 & 0 & 0 & 0 & 0 & 0 & 2 \\
\hline subtotal & $\begin{array}{c}331 \\
(83.4 \%)\end{array}$ & $\begin{array}{c}22 \\
(5.5 \%)\end{array}$ & $\begin{array}{c}18 \\
(4.5 \%)\end{array}$ & 14 & 3 & 9 & 397 \\
\hline \multicolumn{8}{|l|}{$\begin{array}{l}\text { Cytologic diagnosis } \\
\text { (= } 494 \text { cases) }\end{array}$} \\
\hline - unsatisfactory & 9 & 3 & 1 & 0 & 0 & 0 & 13 \\
\hline - benign & 12 & 1 & 3 & 0 & 0 & 0 & 16 \\
\hline $\begin{array}{l}\text { probably } \\
\text { benign }\end{array}$ & 6 & 2 & 0 & 0 & 0 & 0 & 8 \\
\hline - equivocal & 15 & 1 & 4 & 2 & 0 & 1 & 23 \\
\hline $\begin{array}{l}\text { suspicious for } \\
\text { carcinoma }\end{array}$ & $\begin{array}{c}35 \\
(8.7 \%)\end{array}$ & $\begin{array}{c}10 \\
(28.6 \%)\end{array}$ & $\begin{array}{c}4 \\
(14.8 \%)\end{array}$ & 1 & 0 & 2 & 52 \\
\hline $\begin{array}{ll}\text { - } & \text { invasive } \\
& \text { carcinoma }\end{array}$ & $\begin{array}{c}325 \\
(80.8 \%)\end{array}$ & $\begin{array}{c}18 \\
(51.4 \%)\end{array}$ & $\begin{array}{c}15 \\
(55.6 \%\end{array}$ & $\begin{array}{c}14 \\
(82.4)\end{array}$ & 3 & 7 & 382 \\
\hline \multicolumn{8}{|l|}{$\begin{array}{l}\text { Type of error (in } \\
\text { cases not having a } \\
\text { definitive malignant } \\
\text { preoperative } \\
\text { diagnosis = } 112 \\
\text { cases) }\end{array}$} \\
\hline $\begin{array}{ll}\text { - } & \text { interpretation } \\
& \text { error (IE) }\end{array}$ & $\begin{array}{c}31 \\
(40.3 \%) \\
\end{array}$ & $\begin{array}{c}3 \\
(17.6 \%)\end{array}$ & $\begin{array}{c}2 \\
(16.7 \%) \\
\end{array}$ & 1 & 0 & 1 & $\begin{array}{c}38 \\
(339 \%) \\
\end{array}$ \\
\hline $\begin{array}{ll}\text { sampling } \\
\text { error (SE) }\end{array}$ & $\begin{array}{c}43 \\
(57.9 \%)\end{array}$ & $\begin{array}{c}14 \\
(82.4 \%)\end{array}$ & $\begin{array}{c}10 \\
(83.3 \%)\end{array}$ & 2 & 0 & 2 & $\begin{array}{c}74 \\
(66.1 \%)\end{array}$ \\
\hline \multicolumn{8}{|l|}{$\begin{array}{l}\text { Amount of cell } \\
\text { material (evaluated } \\
\text { in } 470 \text { cases) }\end{array}$} \\
\hline - scant & 67 & 13 & 9 & 2 & 0 & 2 & 93 \\
\hline
\end{tabular}




\begin{tabular}{|c|c|c|c|c|c|c|c|}
\hline & $(17.4 \%)$ & $(41.9 \%)$ & $(36 \%)$ & $(11.8 \%)$ & & & \\
\hline - moderate & $\begin{array}{c}111 \\
(28.9 \%)\end{array}$ & $\begin{array}{c}13 \\
(41.9 \%)\end{array}$ & $\begin{array}{c}7 \\
(28 \%)\end{array}$ & $\begin{array}{c}5 \\
(29.4 \%)\end{array}$ & 0 & 2 & 138 \\
\hline - $\quad$ abundant & $\begin{array}{c}206 \\
(53.6 \%)\end{array}$ & $\begin{array}{c}5 \\
(16.1 \%) \\
\end{array}$ & $\begin{array}{c}29 \\
(36 \%)\end{array}$ & $\begin{array}{c}10 \\
(58.8 \%)\end{array}$ & 3 & 10 & 239 \\
\hline $\begin{array}{l}\text { Microcalcification } \\
\text { (evaluated in } 451 \\
\text { cases) }\end{array}$ & & & & & & & \\
\hline present & 173 & 5 & 15 & 4 & 1 & 6 & 204 \\
\hline not present & 198 & 24 & 8 & 12 & 2 & 3 & 247 \\
\hline subtotal & 371 & 29 & 23 & 16 & 3 & 9 & 451 \\
\hline
\end{tabular}

